\section{Zinc Fertilization of Avocado Trees}

\author{
David E. Crowley ${ }^{1}$ and Woody Smith ${ }^{2}$ \\ Department of Soil and Environmental Sciences, University of California, \\ Riverside, CA 92521
}

Ben Faber
University of California, Cooperative Extension, 800 South Victoria Avenue,
L\#1280, Ventura, CA 93009

John A. Manthey ${ }^{4}$

Fruit and Vegetable Chemistry Laboratory, 263, South Chester Avenue, U.S. Department of Agriculture, Agricultural Research Service, Pasadena, CA 91106

Additional index words. foliar applications, surfactant, fertigation, trace metal deficiencies, Persea americana

Abstract. Methods for Zn fertilization of 'Hass' avocado (Persea americana Mill.) trees were evaluated in a 2-year field experiment on a commercial orchard located on a calcareous soil (pH 7.8) in Ventura County, Calif. The fertilization methods included soilor irrigation-applied $\mathrm{ZnSO}_{4}$; irrigation-applied $\mathrm{Zn}$ chelate (Zn-EDTA); trunk injection of $\mathrm{Zn}\left(\mathrm{NO}_{3}\right)_{2}$, and foliar applications of $\mathrm{ZnSO}_{4}, \mathrm{ZnO}$, or $\mathrm{Zn}$ metalosate. Other experiments evaluated the influence of various surfactants on the $\mathrm{Zn}$ contents of leaves treated with foliar-applied materials and on the retention and translocation of radiolabeled ${ }^{65} \mathrm{ZnSO}_{4}$ and ${ }^{65} \mathrm{Zn}$ metalosate after application to the leaf surface. In the field experiment, tree responses to fertilization with soil-applied materials were affected significantly by their initial status, such that only trees having $<50 \mu \mathrm{g} \cdot \mathrm{g}^{-1}$ had significant increases in foliar $\mathrm{Zn}$ contents after fertilization. Among the three soil and irrigation treatments, $\mathrm{ZnSO}_{4}$ applied at $3.2 \mathrm{~kg} \mathrm{ZnSO}$ per tree either as a quarterly irrigation or annually as a soil application was the most effective and increased leaf tissue $\mathrm{Zn}$ concentrations to 75 and $90 \mu \mathrm{g}^{-1}{ }^{-1}$, respectively. Foliar-applied $\mathrm{ZnSO}_{4}, \mathrm{ZnO}$, and $\mathrm{Zn}$ metalosate with $\mathrm{Zn}$ at 5.4, 0.8, and 0.9 g.liter $^{-1}$, respectively, also resulted in increased leaf $\mathrm{Zn}$ concentrations. However, experiments with ${ }^{65} \mathrm{Zn}$ applied to leaves of greenhouse seedlings showed that $<1 \%$ of $\mathrm{Zn}$ applied as $\mathrm{ZnSO}_{4}$ or $\mathrm{Zn}$ metalosate was actually taken up by the leaf tissue and that there was little translocation of $\mathrm{Zn}$ into leaf parenchyma tissue adjacent to the application spots or into the leaves above or below the treated leaves. Given these problems with foliar $\mathrm{Zn}$, fertilization using soil- or irrigation-applied $\mathrm{ZnSO}_{4}$ may provide the most reliable method for correction of $\mathrm{Zn}$ deficiency in avocado on calcareous soils.

Zinc deficiencies are common in many subtropical areas where avocados are grown and are suspected to be an important limiting factor in fruit quality and tree health (Crowley, 1992; Piccone et al., 1985). Deficiencies of Zn typically are associated with calcareous soils in which availability of the metal is limited by its extremely low solubility at alkaline soil $\mathrm{pH}$. Under these circumstances, applications of inorganic fertilizers, such as $\mathrm{ZnSO}_{4}$, result in temporarily increased availability until the metal precipitates out of solution as the poorly soluble oxide. Zinc deficiencies also have

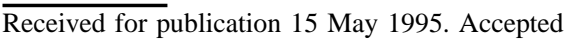
for publication 14 Oct. 1995. This research was supported by a grant from the California Avocado Commission. Mention of a product or trade name does not imply endorsement or recommendation of the product. The cost of publishing this paper was defrayed in part by the payment of page charges. Under postal regulations, this paper therefore must be hereby marked advertisement solely to indicate this fact.

${ }^{1}$ Assistant Professor; to whom reprint requests should be addressed.

${ }^{2}$ Staff Research Associate.

${ }^{3}$ Farm Advisor.

${ }^{4}$ U.S. Dept. of Agriculture Research Chemist. been reported to occur in acid, sandy soils that have low total $\mathrm{Zn}$ contents and in warm, semiarid regions that typically have low soil organic matter. In these cases, the $\mathrm{Zn}$ is relatively soluble but is leached out of the surface soil occupied by the feeder roots. Thus, the strategies that should be used for correction of $\mathrm{Zn}$ deficiency depend largely on the soil $\mathrm{pH}$ and, perhaps, on the amount of organic matter available to form metal complexes (Labanauskas et al., 1959; Srivastava et al., 1981). Other factors that influence $\mathrm{Zn}$ deficiency are high levels of $\mathrm{N}$ and $\mathrm{P}$ fertilizers (Labanauskas et al., 1959) and seasonal fluctuations in leaf micronutrient content (Bingham, 1961; Labanauskas et al., 1961) that may be related to irrigation and climatic factors affecting root growth and nutrient uptake.

Foliar symptoms of Zn deficiency are manifested in the new leaf tissue by a reduction in leaf size and by development of "mottleleaf," which is characterized by interveinal leaf yellowing caused by impaired chlorophyll synthesis. Other symptoms include shortened internode length on the branches, reduced fruit size, and in 'Hass' avocado, the production of round misshapened fruit. The critical $\mathrm{Zn}$ level in the leaf tissue has been established at $20 \mu \mathrm{g} /$ g leaf dry weight (Goodall et al., 1979), with 30 to $150 \mu \mathrm{g} \cdot \mathrm{g}^{-1}$ considered to be normal. Using traditional sampling methods, Zn deficiencies are not always diagnosed easily, with bulk samples collected from the entire orchard, because affected trees frequently occur in clustered groups where the soil is calcareous, or on trees that have feeder roots damaged by phytophthora root rot (Whiley et al., 1987). In some cases, visual leaf yellowing symptoms attributed to $\mathrm{Zn}$ deficiency also may be confused with Fe deficiency, which produces somewhat similar leaf symptoms and can occur simultaneously on calcareous soils. As a result of this confusion and the historical problem with Zn deficiency, avocado growers have used a variety of methods with inconsistent success or they may fertilize an entire orchard to correct a deficiency that is apparent in only a few highly visible trees.

Several methods have been developed to correct $\mathrm{Zn}$ deficiency, including foliar applications of $\mathrm{ZnSO}_{4}$ and $\mathrm{Zn}$ chelates (Goodall et al., 1979; Lee, 1973), trunk injections (Whiley et al., 1991), or soil applications of Zn fertilizers (Embleton et al., 1966; Wallihan et al., 1958). There is no consensus as to which method is the most effective, particularly for orchards on calcareous soils, or which materials are best used with the various application techniques. Foliar application of $\mathrm{Zn}$ fertilizers by helicopter is one of the more common methods used in southern California because of the difficulty of the terrain. However, there is concern as to whether $\mathrm{Zn}$ applied to the outer leaf canopy is translocated to the inner canopy, developing fruit, and roots (Kadman and Lahav, 1978). In some cases, avocado trees produced small, round fruit typical of $\mathrm{Zn}$ deficiency even after the foliage was treated with foliar $\mathrm{Zn}$ (Len Francis, personal communication).

Prior studies on foliar $\mathrm{Zn}$ fertilization of various plants have shown relatively little translocation of foliar-applied $\mathrm{Zn}$ when applied either as $\mathrm{ZnSO}_{4}$ or after chelation with synthetic chelate, such as EDTA. For example in citrus, quantities of $\mathrm{Zn}$ and $\mathrm{Mn}$ translocated from sprayed to new leaves treated with $\mathrm{ZnSO}_{4}$ increased foliar $\mathrm{Zn}$ concentrations by 2 to 5 $\mathrm{mg} \cdot \mathrm{kg}^{-1}$, but only in some years and was considered a negligible effect (Swietlik and LaDuke, 1991). In pea (Pisum sativum L.), only $25 \%$ and $75 \%$ of Zn applied as Zn-EDTA or $\mathrm{ZnSO}_{4}$, respectively, was recovered after removal of epicuticular waxes, of which $\approx 8 \%$ to $10 \%$ was translocated from the treated tissue (Ferrandon and Chamel, 1989). In the only available study on avocado (Kadman and Lahav, 1978), there was no translocation of ${ }^{6} \mathrm{ZnCl}_{2}$ from spots applied to intact leaves, even to adjacent parenchyma tissue. Among the various foliar materials we tested, aminoacid chelates (metalosates) have been taken up and translocated more effectively than inorganic metal salts or the synthetic chelate EDTA in a variety of crops and trees (Hsu, 1986; Shazly, 1986), but to our knowledge, there have been no comparisons of foliar-applied materials for avocado. Recognizing that there are a variety of problems associated with evalu- 
Table 1. Schedule of application methods, Zn materials, and application rates for treatments used to correct Zn deficiency in 'Hass' avocado on a calcareous soil.

\begin{tabular}{|c|c|c|c|c|}
\hline \multirow{2}{*}{$\begin{array}{l}\text { Application } \\
\text { method }\end{array}$} & \multirow{2}{*}{$\begin{array}{c}\mathrm{Zn} \\
\text { material }\end{array}$} & \multirow[b]{2}{*}{$\% \mathrm{Zn}$} & \multicolumn{2}{|r|}{ Application } \\
\hline & & & Rate & Timing \\
\hline Control & $\mathrm{NA}^{2}$ & & NA & \\
\hline \multirow[t]{3}{*}{ Foliar $^{y}$} & Sulfate & 36 & $15 \mathrm{~g} \cdot \mathrm{liter}^{-1}$ & Once per year applied June 1993 and 1994 \\
\hline & Metalosate & 6.8 & $11.7 \mathrm{ml} \cdot \mathrm{liter}^{-1}$ & Once per year applied June 1993 and 1994 \\
\hline & Zintrac 8 & 40 & $2.3 \mathrm{ml} \cdot$ liter $^{-1}$ & Once per year applied June 1993 and 1994 \\
\hline Trunk injection & Nitrate & 34 & $\begin{array}{l}10 \% \mathrm{Zn}\left(\mathrm{NO}_{3}\right)_{2} \text { at } \\
15 \mathrm{ml} \cdot \mathrm{m}^{-1} \text { diameter }\end{array}$ & One time injection Oct. 1992 \\
\hline \multirow[t]{2}{*}{ Simulated irrigation } & Sulfate & 36 & $794 \mathrm{~g} /$ tree & $\begin{array}{l}\text { Quarterly, applied Oct. 1992; Jan., Apr., July, and Oct. } \\
\text { 1993; and Feb., Apr., and July } 1994\end{array}$ \\
\hline & Chelate & 14 & $42 \mathrm{~g} /$ tree & $\begin{array}{l}\text { Quarterly, applied Oct. 1992; Jan., Apr., July, and Oct. } \\
\text { 1993; and Feb., Apr., and July } 1994\end{array}$ \\
\hline Soil banding & Sulfate & 36 & $3.2 \mathrm{~kg} /$ tree & Once per year applied Oct. 1992 and Feb. 1994 \\
\hline
\end{tabular}

${ }^{2} \mathrm{NA}=$ not applicable.

${ }^{\mathrm{y}}$ Foliar materials applied at 900 liters $\mathrm{ha}^{-1}$.

ating avocado tree responses to foliar $\mathrm{Zn}$ fertilizers, this research combined field and laboratory studies to compare the efficacy of soil and foliar Zn fertilization methods for correction of $\mathrm{Zn}$ deficiency in avocado.

\section{Materials and Methods}

Zinc application in orchard. A mature orchard (>15 years old) planted with 'Hass' avocado on Mexican rootstocks was selected after a survey of Zn-deficient orchards throughout Ventura County, Calif. The orchard, under commercial management, was located on a moderately sloping (15\% to $30 \%$ ) hillside on the Las Posas Hills adjacent to the Santa Rosa Valley. Soil on this site was characterized as a Soper loam containing free $\mathrm{CaCO}_{3}$, which was 60 to $150 \mathrm{~cm}$ deep over conglomerate rock. Surface soil $(0$ to $20 \mathrm{~cm}) \mathrm{pH}$ values ranged from 7.8 to 8.0 and were buffered by $0.1 \%$ to $3 \%$ soil carbonate. Patchy areas containing $\mathrm{CaCO}_{3}$ were associated with chlorotic trees that were subsequently determined to be $\mathrm{Fe}$ and $\mathrm{Zn}$ deficient. At the start of the experiment, all of the trees were permanently numbered and mapped, and baseline nutrient analyses were conducted using leaf samples from individual trees. To eliminate possible problems with $\mathrm{Fe}$ and $\mathrm{Mn}$ deficiency, the trees were fertilized with Fe-ethylenediamine di (ohydroxyphenylacetic acid) (EDDHA) (Libfer 6\% Fe; Allied Colloids, Brampton, Ont. Canada) and Mn-EDTA (12\% Mn;W.R. Grace and Co., Lexington, Mass.) at 142 and $57 \mathrm{~g} /$ tree, respectively, using a banded application 0.3 to $1.5 \mathrm{~m}$ from the trunk.

The experiment involved a completely randomized design for the soil- and irrigationapplied materials and individual sets of similar trees for the foliar treatments. The $\mathrm{Zn}$ materials included soil- or irrigation-applied $\mathrm{ZnSO}_{4}(36 \% \mathrm{Zn})$; irrigation-appliedZn-EDTA (14\% Zn) (Librel Zn; Allied Colloids); trunk injection of $\mathrm{Zn}\left(\mathrm{NO}_{3}\right)_{2}(3.5 \% \mathrm{Zn})$; and foliarapplied $\mathrm{ZnSO}_{4}, \mathrm{ZnO}(40 \% \mathrm{Zn})$ (Zintrac-8. Shield Brite Corp., Kirkland, Wash.), or Zn metalosate $(6.8 \% \mathrm{Zn})$ (Albion Laboratories; Clearfield, Utah) using the timing and quantities described in Table 1. Application methods and timing were based on recommended procedures previously developed by farm advisors and commercial applicators or were recommended by the manufacturers of the vari-

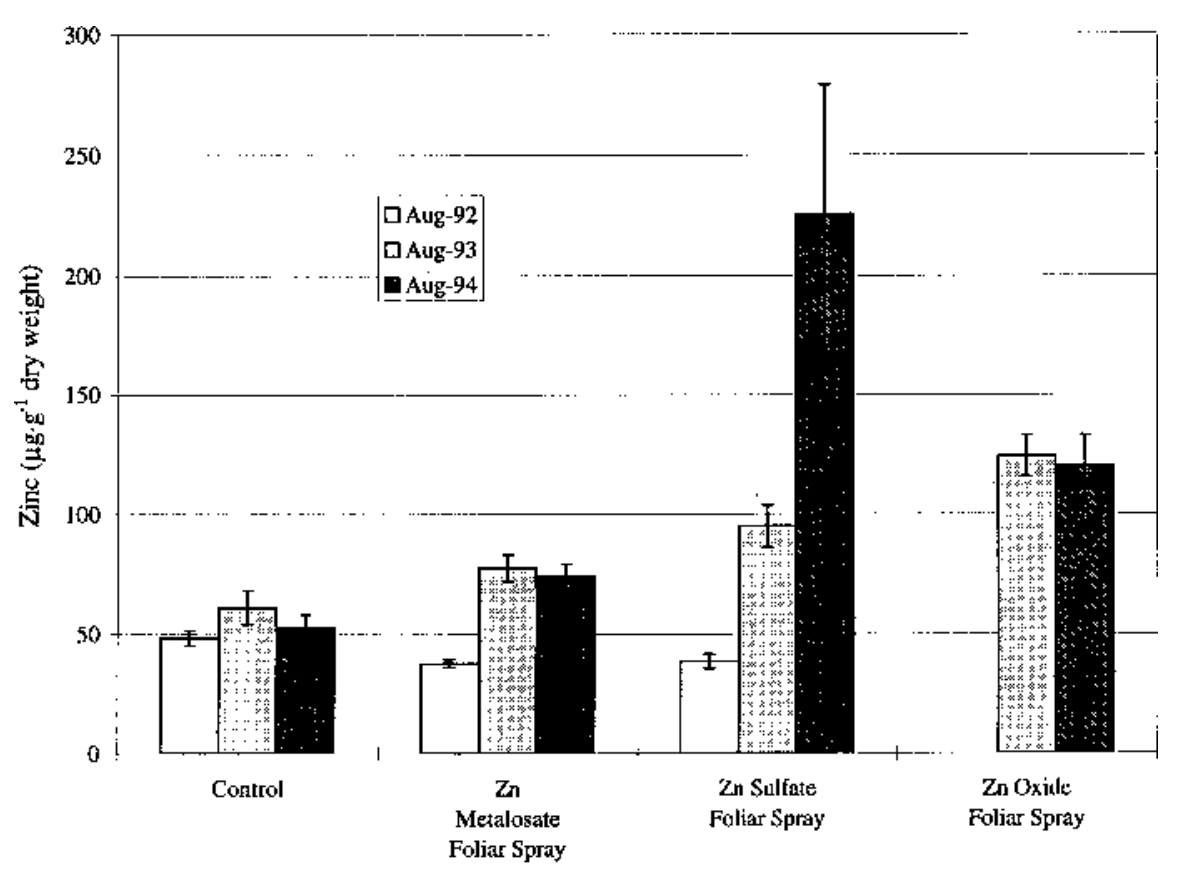

Zinc Treatment

Fig. 1. Zinc concentrations in 'Hass' avocado leaves after foliar application of Zn metalosate $\left(8 \times 10^{-4} \mathrm{~kg}\right.$ $\mathrm{Zn} / \mathrm{liter}), \mathrm{ZnSO}_{4}\left(5.4 \times 10^{-3} \mathrm{~kg} \mathrm{Zn} / \mathrm{liter}\right)$, and $\mathrm{ZnO}\left(9 \times 10^{-4} \mathrm{~kg} \mathrm{Zn} /\right.$ liter $)$. Vertical bars represent sEs of the means within each treatment. All sprays were applied to the canopy to runoff using a commercial spray applicator from ground level. The surfactants, Sun-It II and Kinetic, were used in 1993 and 1994, respectively.

ous compounds. Soil-applied materials were placed in a 1-m-wide band in the minisprinkler irrigation-wetted zone 0.5 to $1.5 \mathrm{~m}$ from the base of the trunk. Irrigation-applied $\mathrm{Zn}$ fertilizer was dissolved in water and applied to the entire sprinkler-wetted soil zone using a watering can. Trunk injection was accomplished using a propane gas-powered gun inserted into a predrilled hole ( $6 \mathrm{~mm}$ in diameter) at the base of each of the main scaffold limbs (Phillips Gas Gun, N.J. Phillips PTY, Somersby, New South Wales, Australia). Injections were conducted early in the morning during the period of active leaf transpiration to reduce back pressure and facilitate rapid uptake into the limbs. Foliar fertilizers were applied to runoff using a gasoline-powered, $\approx 760$-liter spray rig operated at ground level.

Eighteen replicate trees randomly were assigned to each treatment for the soil- and irrigation-applied materials. The number of replications was reduced to 14 to 16 trees for some treatments following an orchard thinning in 1993. Foliar analyses on individual trees receiving either foliar- or soil-applied Zn were conducted yearly to monitor the efficacy of each treatment and the degree of variation that occurred among trees using the various fertilization methods. Yields of 'Hass' or 'Fuerte' avocado trees previously have been unaffected by correcting $\mathrm{Zn}$ deficiency, as documented by a field study conducted over 6 years (Kadman and Lahav, 1978). Thus, data reported in our research focused on changes in foliar $\mathrm{Zn}$ content to compare the efficacy of the Zn fertilizer materials when applied to 'Hass' avocado through the soil and the irrigation water or as a foliar spray. All data were subjected to analysis of variance (ANOVA) using a computer software program (Systat, Evanston, Ill.). When ANOVA generated a significant $\mathrm{F}$ value, mean separations were determined by pairwise $t$ tests for the individual trees in each treatment. In the green- 
house experiment with ${ }^{65} \mathrm{Zn}$ isotope-labeled fertilizers, the data were analyzed by KruskalWallis ANOVA on Ranks, with mean separation by Student-Newman-Keuls all pairwise multiple comparison procedures (Sigma Stat; Jandel Scientific Software, San Rafael, Calif.).

A preliminary experiment examined the $\mathrm{Zn}, \mathrm{Fe}$, and $\mathrm{Mn}$ concentrations for 20 individual leaves collected from four trees to ascertain the appropriate sample size to minimize variation within bulk samples collected from individual trees. Using a sample-size statistical formula, a minimum of 25 leaves per tree was required for most trees to generate a mean value with a $10 \%$ error. Leaf washing procedures used for routine analyses of trees analyzed from Aug. 1992 to Aug. 1993 followed industry standard procedures (Chapman et al., 1978) that use a dilute soap-and-water solution, followed by a tap water and three deionized water rinses. In the foliar fertilization experiment conducted in 1994 to examine surfactants, more stringent procedures were tested in which leaves were washed in a dilute soap-and-water solution, followed by a tap water rinse, and a final $0.1 \mathrm{~N}$ hydrochloric acid wash for varying intervals ranging from $15 \mathrm{sec}$ to $5 \mathrm{~min}$ to dissolve $\mathrm{Zn}$ adhering to the leaf surface. Hydrochloric acid washing previously has been highly effective for removing surface precipitated metals after foliar applications (Ferrandon and Chamel, 1989).

To examine how much $\mathrm{Zn}$ was associated with the epicuticular waxes, subsamples of acid-washed leaves were rinsed in deionized water and further treated with hexane. Subsequent procedures, developed from the leafwashing experiments and used for the surfactant experiments and the main field experiment in 1994, used a dilute soap-and-water wash followed by a tap-water rinse, a deionized-water rinse, a 1-min acid rinse, and three deionized-water rinses.

Leaves processed for analyses after washing were dried in paper bags in a forced-air oven at $60 \mathrm{C}$ for 3 days, after which they were ground with a Wiley mill to pass a 1-mm mesh sieve screen. Weighed subsamples were transferred to Teflon vessels for microwave digestion in 5, 2, and $1 \mathrm{ml}$ of concentrated $\mathrm{HNO}_{3}$, $30 \% \mathrm{H}_{2} \mathrm{O}_{2}$, and deionized water, respectively (Sah et al., 1992). The samples were heated under pressure for $15 \mathrm{~min}$, after which the liquid digests were cooled to room temperature, transferred to $25-\mathrm{ml}$ volumetric flasks, and diluted to a final volume of $25 \mathrm{ml}$ with deionized water. Samples were analyzed using an atomic absorption flame spectrophotometer (model 5000; Perkin Elmer, Norwalk Conn.). Reagent blanks and apple (Malus domestica Borkh.) leaves (model SRM 1515; National Institute of Standards and Technology, Gaithersburg, Md.) were included with each analysis for quality assurance. Measured values for the standard reference materials were generally within $5 \%$ of the reported concentrations.

Evaluation of surfactants. A second experiment, conducted at the Univ. of California Agricultural Expt. Station in Riverside(UCR), examined the effects of three surfactants used in combination with each of the foliar spray fertilizers. All of the materials were applied in Apr. 1994 to newly expanded 'Hass' avocado leaves. The surfactants included a methylated seed oil adjuvant, Sun-It II (American Cyanamid, Grand Forks, Nevada), the industry standard nonionic polyoxyethylenesorbitan detergent Tween 20 (Sigma Chemicals, St. Louis), and a nonionic silicone oil-based surfactant, Kinetic (Setre Chemical Co., Memphis). Twelve leaves per treatment were tagged and sprayed in early morning with each of the

Table 2. Foliar concentrations of $\mathrm{Zn}$ for trees with low and high $\mathrm{Zn}$ contents before fertilization with soiland irrigation-applied Zn fertilizers in 1992 and after fertilization in 1993 and 1994.

\begin{tabular}{lccccc}
\hline \hline & & \multicolumn{4}{c}{ Foliar Zn concn $\left(\mu \mathrm{g} \cdot \mathrm{g}^{-1}\right)$} \\
\cline { 3 - 6 } Treatment & No. $^{\mathrm{z}}$ & Initial tree status & $1992^{\mathrm{y}}$ & 1993 & 1994 \\
\hline None (control) & 8 & $<50$ & $38(1.9)$ & $40(2.8)$ & $37(3.0)$ \\
& 10 & $\geq 50$ & $57(1.9)$ & $54(6.7)$ & $43^{* *}(2.1)$ \\
Zn-EDTA irrigation & 6 & $<50$ & $41(3.3)$ & $73^{*}(14.1)$ & $57(14.1)$ \\
& 10 & $\geq 50$ & $58(1.6)$ & $50(3.9)$ & $44(3.1)$ \\
$\mathrm{ZnSO}_{4}$ irrigation & 9 & $<50$ & $37(2.0)$ & $75^{* *}(5.4)$ & $86^{* *}(7.6)$ \\
& 5 & $\geq 50$ & $57(2.1)$ & $56(5.8)$ & $55(4.7)$ \\
$\mathrm{ZnSO}_{4}$ soil banded & 12 & $<50$ & $38(1.8)$ & $86^{* *}(8.9)$ & $99^{* *}(9.4)$ \\
& 4 & $\geq 50$ & $58(2.5)$ & $103(32.2)$ & $61(21.4)$
\end{tabular}

${ }^{2}$ Number of replicate trees after random assignment to the various fertilizer treatments.

${ }^{y}$ Values for trees having low and high Zn contents in 1992 are before fertilization with $\mathrm{Zn}$. Values in parentheses are SE of the mean.

",**Significant at $P \leq 0.05$ or 0.01 , respectively, between 1992 and 1993 and between 1992 and 1994 using a pairwise $t$ test comparing changes in foliar $\mathrm{Zn}$ concentrations for individual trees.

Table 3. Two-way analysis of variance of avocado tree responses to soil fertilizer treatments and effect of initial tree status in 1992 before fertilization.

\begin{tabular}{lccccc}
\hline & \multicolumn{5}{c}{ Analysis of variance } \\
\cline { 2 - 6 } Source & Sum of squares & df & Mean square & F ratio & $P$ \\
\hline Treatment & 13,097 & 3 & 4,365 & 8.963 & 0.000 \\
Category $^{z}$ & 4,750 & 1 & 4,750 & 9.753 & 0.003 \\
Treatment $\times$ category & 4,093 & 3 & 1,364 & 2.801 & 0.048 \\
Error & 26,790 & 55 & 487 & &
\end{tabular}

${ }^{2}$ Trees were divided into two categories depending on their initial foliar $\mathrm{Zn}$ contents: trees with $<50$ $\mu \mathrm{g} \cdot \mathrm{g}^{-1}$ and trees initially having $>50 \mu \mathrm{g} \cdot \mathrm{g}^{-1}$.

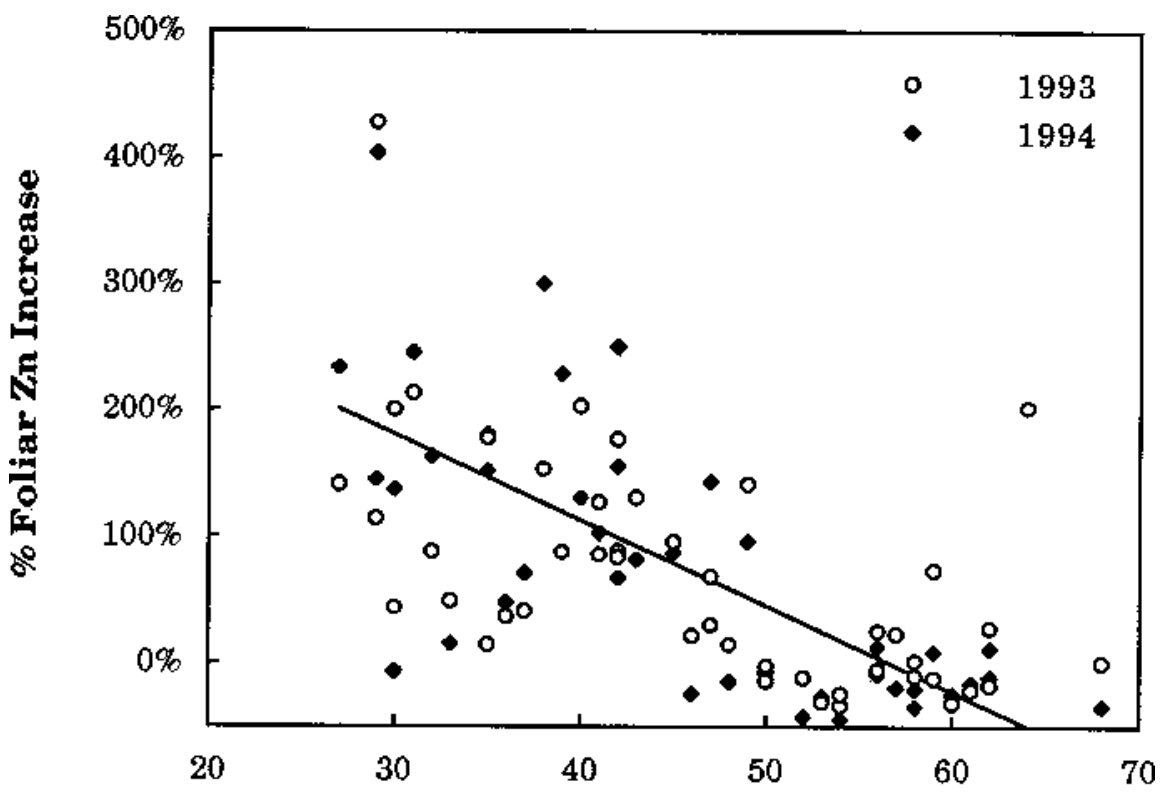

\section{Initial Zn Content}

Fig. 2. 'Hass' avocado responses to soil applications of $\mathrm{Zn}$ fertilizers as affected by their initial $\mathrm{Zn}$ status. Line was fit to data points by regression analysis $(r=0.704)$. 
Del.) with 6-month-old, container-grown avocado seedlings. The isotope was purchased as $\mathrm{Zn}$ chloride in $0.5 \mathrm{~N} \mathrm{HCl}$ (specific activity 5.5 $\left.\times 10^{8} \mathrm{~Bq} \cdot \mathrm{mg}^{-1}\right)$. Zinc metalosate was prepared by complexation with a proprietary aminoacid hydrolysate by Albion Laboratories, who provided technical support and materials used for preparation of the radiolabeled chelate at UCR. Zinc metalosate contains $7 \% \mathrm{Zn}$ by weight with a specific gravity of 1.25 . The $\mathrm{Zn}$ complex, containing $3.7 \times 10^{6} \mathrm{~Bq} \cdot \mathrm{ml}^{-1}$, had a specific activity of $43.7 \mathrm{~Bq} \cdot \mu^{-1} \mathrm{Zn}$. Radiolabeled $\mathrm{ZnSO}_{4}$ was prepared at a $6.5 \%(\mathrm{v} / \mathrm{v})$ concentration by adding $20 \mu \mathrm{l}$ of ${ }^{65} \mathrm{ZnCl}_{2}$ to $180 \mu \mathrm{l}$ of $1.1 \mathrm{M} \mathrm{ZnSO}_{4}$. Taking into account the concentration of $\mathrm{HCl}$ added with the isotope, the final solution was $\approx 95 \% \mathrm{ZnSO}_{4}$ and $5 \%$ $\mathrm{ZnCl}_{2}$ and had a specific activity of 57 $\mathrm{Bq} \cdot \mu \mathrm{g}^{-1} \mathrm{Zn}$

To examine differential absorption into the upper or lower sides of the leaves, $1-\mathrm{cm}^{2}$ spots of the radiolabeled materials were applied to individual leaves of greenhouse, containergrown avocado seedlings using five replicate trees per treatment. Mean dry weight of the treated spots was $8 \mathrm{mg} \cdot \mathrm{cm}^{-2}$. Leaves selected for treatment were all newly expanded leaves located three leaves down from the stem apex. After the leaves were treated in the morning, the materials were allowed to absorb into the leaf tissue for 3 days. The treated leaves then were analyzed individually by removing the leaf and excising the application spot with a razor blade. The excised tissue containing the application spots was treated by washing in vials containing $10 \mathrm{ml}$ soap and water for 1 min, followed by a 10-ml water rinse; a 1-min, 10-ml acid wash; and a final water rinse, using separate vials for each sample at each step. Each of the wash solutions was analyzed for ${ }^{65} \mathrm{Zn}$ by liquid-scintillation counting of $1-\mathrm{ml}$ samples to determine a mass balance for the isotope. Translocation into adjacent leaves was measured by sampling of the first leaf immediately above and below the treated leaf, the leaf tissue adjacent to the application spot, and the stem apex of each plant. Leaf content of ${ }^{65} \mathrm{Zn}$ was determined using standard procedures with a liquid-scintillation counter (model LS5000 TD; Beckman, Fullerton, Calif.).

\section{Results and Discussion}

Zn application in orchard. The mean foliar $\mathrm{Zn}$ content for all trees in this orchard before fertilization was $\approx 45 \mu \mathrm{g} \cdot \mathrm{g}^{-1}$, although several individual trees were marginally $\mathrm{Zn}$ deficient (normal $\mathrm{Zn}$ range $=30$ to $150 \mu \mathrm{g} \cdot \mathrm{g}^{-1}$ ). In our experience, variability in foliar $\mathrm{Zn}$ concentrations in an orchard and within the canopy of individual trees is typical of $\mathrm{Zn}$ and Fe deficiency problems and appears to be associated with high $\mathrm{CaCO}_{3}$ concentrations in calcareous soils. We report our leaf analysis data for 1992 (see Fig. 1 and Table 2) as the statistical means for each treatment before applying the fertilizer materials, whereas data for Aug. 1993 and 1994 are for the same trees after fertilization. An initial analysis of the data revealed that trees with $>50 \mu \mathrm{g} \cdot \mathrm{g}^{-1}$ did not respond significantly to any of the soil-applied fertilizer ma-

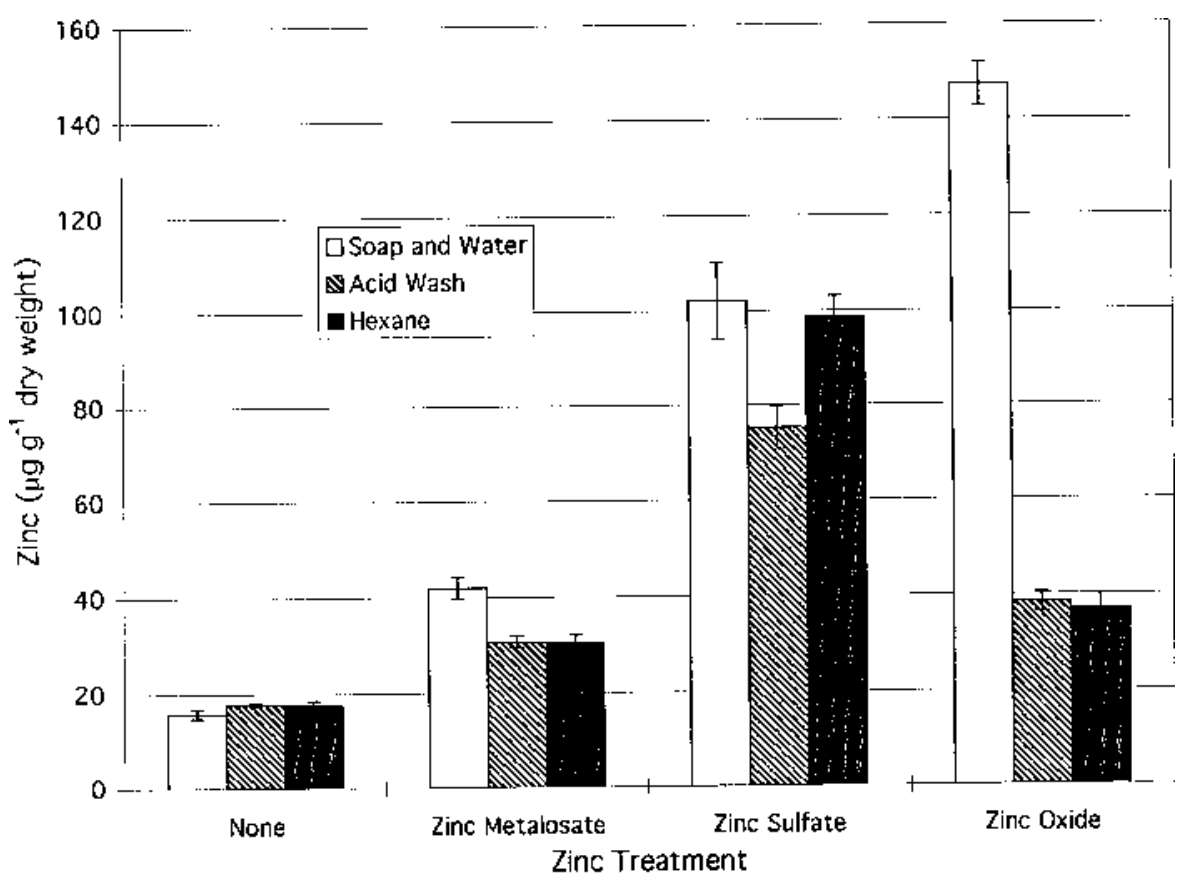

Fig. 3. Successive washing treatments for avocado leaves for removal of extracellular $\mathrm{Zn}$ applied as $\mathrm{Zn}$ metalosate, $\mathrm{ZnSO}_{4}$, or $\mathrm{ZnO}$ after foliar application in a water base with no surfactant. Vertical bars represent SES of the means within each treatment. Leaves were processed $4 \mathrm{~h}$ after application.

Table 4. Wash removal and leaf retention (percent of that applied) of foliar-applied, radiolabeled $\mathrm{ZnSO}_{4}$ and $\mathrm{Zn}$ metalosate by leaves of greenhouse-grown avocado seedlings 3 days after application to the adaxial or abaxial side of the leaf surface.

\begin{tabular}{|c|c|c|c|c|}
\hline \multirow{2}{*}{$\begin{array}{l}\text { Removal } \\
\text { method }\end{array}$} & \multicolumn{2}{|c|}{$\mathrm{ZnSO}_{4}$} & \multicolumn{2}{|c|}{ Zn metalosate } \\
\hline & Adaxial & Abaxial & Adaxial & Abaxial \\
\hline Soap and water & $96.5 \mathrm{a}(2.5)^{\mathrm{z}}$ & 96.8 a $(0.9)$ & 98.4 a $(0.6)$ & $92.8 \mathrm{~b} \mathrm{(2.8)}$ \\
\hline Water rinse & $1.7 \mathrm{a}(1.8)$ & $1.3 \mathrm{a}(0.5)$ & $0.8 \mathrm{a}(0.2)$ & $1.3 \mathrm{a}(0.4)$ \\
\hline Acid wash & $1.0 \mathrm{ab}(0.5)$ & $1.0 \mathrm{ab}(0.2)$ & $0.6 \mathrm{~b}(0.4)$ & $1.6 \mathrm{a}(0.8)$ \\
\hline Retained by leaf & $0.7 \mathrm{a}(0.4)$ & 0.9 a $(0.1)$ & $0.2 \mathrm{a}(0.1)$ & $4.2 \mathrm{~b}(2.5)$ \\
\hline
\end{tabular}

${ }^{2}$ Values in parentheses are SE of the means. Mean separation within rows by Tukey's honestly significant difference at $P \leq 0.05$.

terials (Table 3) and that the relative response with respect to percent increase in foliar $\mathrm{Zn}$ was correlated $(r=0.70)$ with the initial $\mathrm{Zn}$ content of the trees before fertilization (Fig. 2). All subsequent comparisons of treatment means for soil- or irrigation-applied $\mathrm{Zn}$ were filtered for trees having low and high initial $\mathrm{Zn}$ concentrations (Table 2).

Almost all of the $\mathrm{Zn}$ fertilization methods resulted in increased foliar $\mathrm{Zn}$ concentrations, with the exception of irrigation-applied $\mathrm{Zn}$ EDTA in 1994 and trunk injection of $\mathrm{Zn}\left(\mathrm{NO}_{3}\right)_{2}$. Trunk injection was tested only one time (Fall 1992) and gave a short-term response in which foliar $\mathrm{Zn}$ concentrations transiently increased from 40 to $65 \mu \mathrm{g} \cdot \mathrm{g}^{-1}$ in the spring but dropped to control levels by the following August. The 6-mm holes that were drilled into each of the major scaffold limbs healed slowly and continued to exude sap for several months. This treatment was judged to be potentially dangerous because it could allow introduction of Phytophthora citricola into the wounds, which is associated opportunistically with trunk wounding and desuckering in California avocado orchards (El-Hamalawi et al., 1994). Therefore, the treatment was discontinued.

Applications to soil. Among the three soil and irrigation treatments, the least effective and most expensive was Zn-EDTA chelate applied at the relatively low rate (43 $\mathrm{g} \mathrm{Zn}$ per tree) recommended by the manufacturer. Leaf $\mathrm{Zn}$ concentrations of trees initially having $\mathrm{Zn}$ at $<50 \mu \mathrm{g} \cdot \mathrm{g}^{-1}$ increased from a mean level of 41 to 73 and $57 \mu \mathrm{g} \cdot \mathrm{g}^{-1}$ in 1993 and 1994, respectively, after fertilization with Zn-EDTA, but this increase was highly variable and not significantly different $(P>0.05)$ from the $\mathrm{Zn}$ in the unfertilized control trees (Table 2). One reason for this result may be displacement of $\mathrm{Zn}$ from the chelate by $\mathrm{Ca}$ (Norvell et al., 1969), which was present in large quantities in the soil as $\mathrm{CaCO}_{3}$.

The most effective soil fertilizer was $\mathrm{ZnSO}_{4}$ applied at an annual rate of $3.2 \mathrm{~kg} \mathrm{ZnSO}_{4}$ per tree, either quarterly as a simulated irrigation or annually as a single soil application, which increased foliar $\mathrm{Zn}$ concentrations in low-Znstatus trees to 75 and $86 \mu \mathrm{g} \cdot \mathrm{g}^{-1}$ in 1993 and 86 and $99 \mu \mathrm{g} \cdot \mathrm{g}^{-1}$ in 1994 . In contrast, there were no significant increases in foliar $\mathrm{Zn}$ for trees initially having $\mathrm{Zn}$ at $>50 \mu \mathrm{g} \cdot \mathrm{g}^{-1}$ (Table 2 ). One possible exception was noted for trees receiving $\mathrm{ZnSO}_{4}$ by soil banding in which $\mathrm{Zn}$ levels increased from 58 to $103 \mu \mathrm{g} \cdot \mathrm{g}^{-1}$ in 1993. These levels decreased in the following year to $61 \mu \mathrm{g} \cdot \mathrm{g}^{-1}$. Due to the few trees in the high- $\mathrm{Zn}$ category-treatment combination $(n=4)$, the 
transient increase of 1993 was not statistically significant.

The lack of response of trees in the initially high-Zn category and the lack of further increase in foliar $\mathrm{Zn}$ after the second fertilizer applications suggests that avocado roots may regulate $\mathrm{Zn}$ uptake to maintain levels between 50 and $100 \mu \mathrm{g} \cdot \mathrm{g}^{-1}$ in the foliage. The longevity of the soil fertilizer treatments needs to be monitored to determine the frequency of fertilizer application that is necessary to maintain adequate foliar $\mathrm{Zn}$ contents. An important consideration with long-term use of the soil treatments is the total quantity of $\mathrm{Zn}$ that is being applied. After two successive applications, $2.4 \mathrm{~kg}$ of actual $\mathrm{Zn}$ had been applied per tree, which, in a $10-\mathrm{m}^{2}$ area, is equivalent to $144 \mu \mathrm{g} \cdot \mathrm{g}^{-1}$ in the upper $10 \mathrm{~cm}$ of soil. Continued annual applications may exceed the legally allowable quantities of $\mathrm{Zn}$, which at high levels becomes a soil pollutant. Current Environmental Protection Agency (EPA) guidelines for $\mathrm{Zn}$ are $2800 \mathrm{~g} \cdot \mathrm{g}^{-1}$ soil as a pollutant concentration limit and an annual pollutant loading at $140 \mathrm{~kg} \cdot \mathrm{ha}^{-1} \cdot \mathrm{yr}^{-1}$, or $63 \mu \mathrm{g} \cdot \mathrm{g}^{-1}$ when applied as an organic soil amendment (EPA, 1994). Once the $\mathrm{Zn}$ has been applied to the soil, other options would be to lower the surface soil $\mathrm{pH}$ by applying granular $\mathrm{S}$ or using acidic $\mathrm{N}$ or $\mathrm{P}$ fertilizers supplied with the irrigation water.

Foliar treatments. By weighing representative leaves before and after spraying, we determined that as much as $1 \mathrm{ml}$ of spray may be retained on the surface of an individual leaf. If all of this material dried on the leaf surface and is not removed by washing, this wetness would result in more than several thousand micrograms $\mathrm{Zn}$ per gram associated with the leaf tissue. Thus, there is an inherent problem in evaluating the efficacy of foliar-applied materials because any residual extracellular $\mathrm{Zn}$ may be artifactually interpreted as an increase in leaf tissue $\mathrm{Zn}$ content. During this research, various leaf washing methods were assessed to determine how much of the foliarapplied $\mathrm{Zn}$ could be removed from the leaf surface using industry standard procedures: 1 ) a soap-and-water wash, 2) more stringent washing with hydrochloric acid, or 3) removal of the cuticle by treatment with hexane. We used highly controlled conditions in which individual leaves of trees at the UCR field station were treated with fertilizers sprayed on to the upper leaf surfaces. Preliminary experiments showed that soap-and-water washing of the tissue resulted in the removal of $>95 \%$ of foliar-applied $\mathrm{Zn}$ but left residual $\mathrm{Zn}$ that could be removed by a subsequent acid-wash of the leaves (Fig. 3). This aspect was particularly evident for leaves treated with $\mathrm{ZnO}$, which contained $\mathrm{Zn}$ at $145 \mu \mathrm{g} \cdot \mathrm{g}^{-1}$ after soap and water but only $40 \mu \mathrm{g} \cdot \mathrm{g}^{-1}$ after a subsequent acid wash. No further decreases in $\mathrm{Zn}$ content occurred with subsequent washing steps or after removal of the cuticle by treatment with hexane. Results were similar with respect to leaf washing in the experiment with ${ }^{65} \mathrm{ZnSO}_{4}$ and ${ }^{65} \mathrm{Zn}$ metalosate (Table 4). The small amount of foliar $\mathrm{Zn}$ that remained on the leaf represented from 10 to $80 \mu \mathrm{g} \cdot \mathrm{g}^{-1}$, of which an unknown proportion would be metabolically available. Thus, analysis of sprayed leaf tissue does not indicate physiological effectiveness of the spray.

Results of the field experiment at the Ventura County field site in 1993 and 1994 showed that all three of the foliar $\mathrm{Zn}$ fertilizers resulted in an increase in foliar $\mathrm{Zn}$ concentrations at the time of leaf analysis in August, 4 months after the materials had been applied (Fig. 1). When applied with a methylated, seed-oil adjuvant (Sun-It II), the mean leaf $\mathrm{Zn}$ concentrations in 1993 were 75,100 , and 125 $\mu \mathrm{g} \cdot \mathrm{g}^{-1}$ for $\mathrm{Zn}$ metalosate, $\mathrm{ZnSO}_{4}$, and $\mathrm{ZnO}$, respectively. In 1994, a different surfactant, (Kinetic) with better dispersion properties was used but resulted in similar $\mathrm{Zn}$ contents to those measured the previous year, except for $\mathrm{ZnSO}_{4}$, which increased leaf $\mathrm{Zn}$ concentrations to $220 \mu \mathrm{g} \cdot \mathrm{g}^{-1}$.

Surfactant effects on foliar Zn absorption. Among the three surfactants we tested, the organosilicone-based material Kinetic gave superior leaf coverage, which is one of the most important properties of a good surfactant. However, with one exception, the individual surfactants had no statistically significant effects on foliar $\mathrm{Zn}$ contents immediately after application or at any of the subsequent leaf sampling dates. Because there were no statistically significant changes over time, the cumulative data for all sampling dates were reduced to a single mean for each of the surfactant-fertilizer treatments (Fig. 4). Zinc in control leaves was at $\approx 32 \mu \mathrm{g} \cdot \mathrm{g}^{-1}$, whereas leaves treated with $\mathrm{ZnSO}_{4}, \mathrm{ZnO}$, and $\mathrm{Zn}$ metalosate had mean $\mathrm{Zn}$ concentrations of 94 , 43 , and $47 \mu \mathrm{g} \cdot \mathrm{g}^{-1}$, respectively, when applied in water with no surfactant. WithZn metalosate, the surfactants Tween 20 and Sun-It II actually appeared to inhibit absorption of the fertilizer $(P=0.12)$. The only positive benefit of a surfactant with any of the fertilizer materials was Sun-It II with $\mathrm{ZnO}$. Here, foliar $\mathrm{Zn}$ concentrations increased to $97 \mu \mathrm{g} \cdot \mathrm{g}^{-1}$, which was significantly different $(P>0.01)$ from all other surfactants with this fertilizer. One possible reason for this effect might be that the insoluble $\mathrm{ZnO}$ was partially solubilized to form a water-soluble complex with components of the surfactant.

To study leaf retention and translocation of $\mathrm{Zn}$ provided as foliar-applied $\mathrm{ZnSO}_{4}$ and $\mathrm{Zn}$ metalosate, experiments were conducted with ${ }^{65} \mathrm{Zn}$-radiolabeled materials applied as spots to either the top or bottom of the leaf surfaces of greenhouse, container-grown trees. Results of these experiments showed that generally $<1 \%$

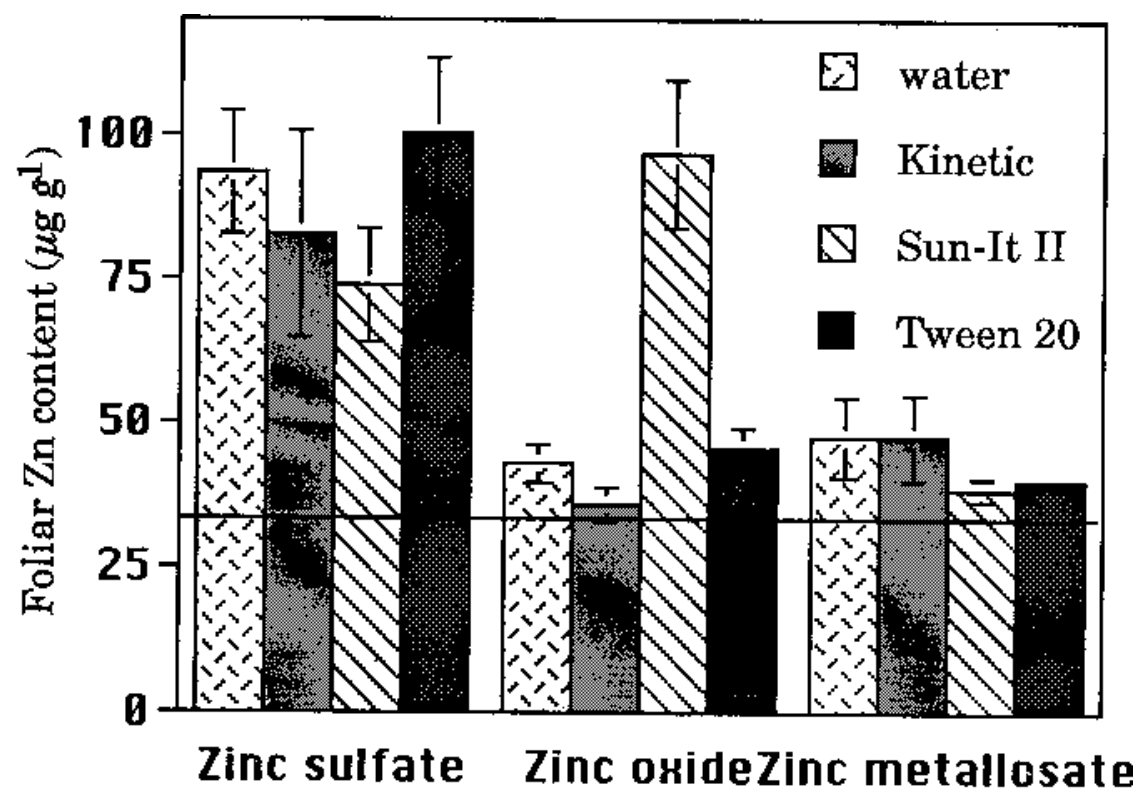

Fig. 4. Zinc contents of avocado leaves treated with $\mathrm{ZnSO}_{4}, \mathrm{ZnO}$, or $\mathrm{Zn}$ metalosate as affected by various surfactants. Vertical bars represent SES of the means within each treatment. Horizontal line indicates the $\mathrm{Zn}$ content of nontreated control leaves that had a mean $\mathrm{Zn}$ content of $32 \mu \mathrm{g} \cdot \mathrm{g}^{-1}$ and a SE of 1.3 . There were no statistically significant effects of the surfactants, except for the treatment with Sun-It II when used with $\mathrm{ZnO}$ ( $P \leq 0.05$ by Tukey's honestly significant difference).

Table 5. Translocation and quantities of $\mathrm{Zn}$ (in nanograms) retained by avocado leaves treated with radiolabeled $\mathrm{ZnSO}_{4}$ or $\mathrm{Zn}$ metalosate after application to the adaxial or abaxial leaf surfaces of greenhouse, container-grown seedlings.

\begin{tabular}{|c|c|c|c|c|}
\hline \multirow{2}{*}{$\begin{array}{l}\text { Removal } \\
\text { method }\end{array}$} & \multicolumn{2}{|c|}{$\mathrm{ZnSO}_{4}$} & \multicolumn{2}{|c|}{ Zn metalosate } \\
\hline & Adaxial & Abaxial & Adaxial & Abaxial \\
\hline Stem apex & 50 a $(20)^{z}$ & 18 a (5) & $11 \mathrm{a}(4)$ & 37 a (26) \\
\hline Leaf, adaxial & 47 a (23) & 37 a (8) & 19 a (4) & 22 a (5) \\
\hline Leaf, abaxial & 30 a (9) & 26 a (7) & 24 a (5) & 38 a (6) \\
\hline Adjacent tissue & 223 a (55) & 95 a (54) & $16 \mathrm{~b}(5)$ & 394 a (118) \\
\hline Application spot & 276 a (51) & $1,700 \mathrm{~b}(306)$ & 586 a (105) & 13,995 c $(3057)$ \\
\hline
\end{tabular}

${ }^{z}$ Values in parentheses are ses of the means. Mean separation within rows by Student-Newman-Keuls all pairwise multiple comparison procedures at $P \leq 0.05$. 
of the applied $\mathrm{Zn}$ was retained by the leaf surface after the treated spots were washed in soap and water followed by an acid wash (Table 4). One exception was with $\mathrm{Zn}$ metalosate, in which $3.8 \%$ of the total material applied was retained when the fertilizer was applied to the bottom side of the leaf. After determining leaf weight of the treated spots, the amounts retained by the leaf tissue were equivalent to increases in $\mathrm{Zn}$ content of 35 and $72 \mu \mathrm{g} \cdot \mathrm{g}^{-1}$ for $\mathrm{ZnSO}_{4}$ and $\mathrm{Zn}$ metalosate, respectively, when the fertilizers were applied to the upper leaf surface. These values are within the same range observed for foliar fertilizer-treated trees in the field experiments. There was no statistically significant difference between $\mathrm{ZnSO}_{4}$ and $\mathrm{Zn}$ metalosate when applied to the upper leaf surface. However, retention of $\mathrm{ZnSO}_{4}$ and $\mathrm{Zn}$ metalosate was significantly increased (6- and 24-fold, respectively) when applied to the abaxial leaf surface compared to the amounts retained when applied to the adaxial surface (Table 5).

Of the small amounts of radiolabel retained by the leaves treated with ${ }^{65} \mathrm{ZnSO}_{4}$ on the adaxial leaf surfaces, about half was translocated into the adjacent leaf parenchyma tissue, and $5 \%$ to $8 \%$ was translocated into the leaf apex and leaves above and below the treated leaf. Although much higher levels of $\mathrm{Zn}$ were associated with the $\mathrm{Zn}$ application spots on the abaxial sides of the leaves, there were no differences in the actual quantities translocated to the other leaves or adjacent parenchyma tissue. Similar trends were observed with $\mathrm{Zn}$ metalosate, but much smaller percentages of the total $\mathrm{Zn}$ retained by the plant tissue were translocated out of the application spots. With $\mathrm{Zn}$ metalosate, only $2 \%$ to $4 \%$ of the total $\mathrm{Zn}$ retained was located in the apex tissue or leaves above and below the treated leaves. These data confirm that there is relatively little translocation of $\mathrm{Zn}$ from leaves treated with a foliar spray and suggests over the short term that there is no significant difference in the efficacy of $\mathrm{Zn}$ metalosate vs. $\mathrm{ZnSO}_{4}$ for treatment of $\mathrm{Zn}$ deficiency in avocado.

Although foliar feeding is used to supply trace metals to a variety of ornamentals and tree fruit crops, different plant species vary with respect to their cuticle thickness and physiological characteristics that may influence the absorption and translocation of fertilizers. In trees, such as citrus, which have been studied much more extensively than avocado, absorption of trace metals also has been influenced by the formulation of the spray mixture and the type of surfactant (Alva et al., 1992). Paradoxically, neither avocado (Kadman and Lahav, 1978) nor citrus (Embleton et al., 1965; Labanauskas and Puffer, 1964; Swietlik and LaDuke, 1991) have responded to Zn applications with respect to yield increases. This research confirmed the poor mobility of foliar-applied $\mathrm{Zn}$, whether it is applied as an inorganic salt or synthetic chelate, and is in agreement with earlier research on avocado and citrus (Ferrandon and Chamel, 1989; Kadman and Lahav, 1978). Thus, foliar applications are primarily useful for correcting $\mathrm{Zn}$ deficiency in the treated foliage, and their efficacy cannot be evaluated by monitoring changes in adjacent nontreated leaves or by increases in fruit yield. Under field conditions, the amount of liquid spray applied to the leaves during foliar applications, and the time it will remain soluble before drying on the leaf surface, will depend on the application method and a variety of factors, such as location within the canopy, wind drift, air temperature, and humidity. As shown in our research, there also may be differential absorption of the materials by the upper and lower leaf surfaces, which have different cuticle thickness and stomatal densities.

\section{Conclusion}

This research revealed that there are critical problems in evaluating the efficacy of foliar sprays due to potential artifacts associated with the retention of extracellular $\mathrm{Zn}$ precipitates on avocado leaves. Results of experiments with radioisotope-labeled fertilizers suggested that, in some cases, foliar fertilization may supply small amounts of $\mathrm{Zn}$. The efficacy of the $\mathrm{Zn}$ application will depend on the percentage of the tree leaf area that receives the $\mathrm{Zn}$ spray. If all leaves receive $\mathrm{Zn}$ spray, then the $5 \%$ translocated $\mathrm{Zn}$ may be adequate to supply new growth and buds with $\mathrm{Zn}$. Some calculations based on leaf area, total $\mathrm{Zn}$ applied, total translocatable $\mathrm{Zn}$, and drymatter production over 1 year might give some clues as to potential efficacy. However, given the uncertainty as to whether foliar-applied $\mathrm{Zn}$ fertilizers can satisfy the $\mathrm{Zn}$ requirement of the entire tree and the expense of helicopter applications of $\mathrm{Zn}$ fertilizers, soil application of $\mathrm{Zn}$ appears to be a more reliable and simpler fertilization method. Zinc fertilization may be accomplished by using $\mathrm{ZnSO}_{4}$ in a band applied under the irrigated sprinkler zone of the canopies of $\mathrm{Zn}$-deficient trees or by adding solubilized $\mathrm{ZnSO}_{4}$ to the irrigation water.

\section{Literature Cited}

Alva, A.K. and D.P.H. Tucker. 1992. Foliar application of various sources of iron, manganese, and Zn to citrus. Proc. Fla. State Hort. Soc. 105:7073.

Bingham, F.T. 1961. Seasonal trends in nutrient composition of 'Hass' avocado leaves. J. Amer. Soc. Hort. Sci. 78:149-160

Chapman, H.D. and P.F. Pratt. 1978. Methods of analysis for soils, plants, and waters. Univ. of California Press, Berkeley, Calif.

Crowley, D.E. 1992. Soil fertility and the mineral nutrition of avocado. Circ. CAS-92/1. Publication produced and distributed jointly by the California Avocado Development Organization and The California Avocado Society, Saticoy, Calif.

El-Hamalawi, Z.A., E.C. Pond, and J.A. Menge. 1994. Effect of leaf removal and plant pruning on the development of stem canker disease caused by Phytophthora citricola on Persea americana and Persea indica. Calif. Avocado Soc. Yrbk. 78:131-142.

Embleton, T.W. and E.F. Wallihan. 1966. Soil applications of $\mathrm{Zn}$ for avocados. Calif. Avocado Soc. Yrbk. 50:87-93.
Embleton, T.W., E.F. Wallihan, and G.E. Goodall. 1965. Effectiveness of soil vs. foliar applied Zn and foliar applied manganese on California lemons. Proc. Amer. Soc. Hort. Sci. 86:253-259.

Environmental Protection Agency. 1994. A plain English guide to the EPA Part 503 biosolids rule. EPA/832/R-93/003. U.S. Environmental Protection Agency, Office of Wastewater Management, Washington D.C.

Ferrandon, M. and A. Chamel. 1989. Foliar uptake and translocation of iron, zinc, and manganese. Influence of chelating agents. Plant Physiol. Biochem. 27:713-722.

Goodall, G.E., T.W.Embleton, and R.G. Platt. 1979. Avocado fertilization. Univ. of California Coop. Ext. Bul. 2024.

Hsu, H.H. 1986. The absorption and distribution of metalosates from foliar fertilization, p. 236254. In: H. DeWayne Ashmead (ed.). Foliar feeding of plants with amino acid chelates. Noyes Publ., Park Ridge, N.J.

Kadman, A. and E. Lahav. 1978. Experiments with zinc supply to avocado trees, p. 225-230. In: Proc. of the 8th Intl. Colloq. Plant Analysis and Fertilizer Problems. Auckland, New Zealand, 28 Aug.-6 Sept. 1978.

Labanauskas, C.K., T.W.Embleton, and W.W.Jones. 1959. Fertilizer effects on micronutrient nutrition in avocado. Calif. Avocado Soc. Yrbk. 43:96-99.

Labanauskas, C.K., T.W. Embleton, W.W. Jones, and M.J. Garber. 1961. Seasonal changes in concentrations of zinc, copper, boron, manganese, and iron in Fuerte avocado leaves. Proc. Amer. Soc. Hort. Sci. 77:173-179.

Labanauskas, C.K. and R.E. Puffer. 1964. Effect of foliar applications of manganese, zinc, and urea on 'Valencia' orange yield and foliage composition. HortScience 82:142-153.

Lee, B.W. 1973. The efficacy of aerial applications of zinc to avocado trees. Calif. Avocado Soc. Yrbk. 56:121-123.

Norvell, W.A. and W.L. Lindsay. 1969. Reactions of EDTA complexes of $\mathrm{Fe}, \mathrm{Zn}, \mathrm{Mn}$, and $\mathrm{Cu}$ in soils. Soil Sci. Soc. Amer. J. 33:86-91.

Piccone, M.F. and A.W. Whiley. 1985. Recognize boron and zinc deficiency in avocado. Queensland Fruit and Veg. News 55:19-20.

Sah, R.N. and R.O. Miller. 1992. Spontaneous reaction for acid dissolution of biological tissues in closed vessels. Anal. Chem. 64:230-233.

Shazly, S.A. 1986. The effect of amino acid chelated minerals in correcting mineral deficiencies and increasing fruit production in Egypt, p. 289299. In: H. DeWayne Ashmead (ed.). Foliar feeding of plants with amino acid chelates. Noyes Publ., Park Ridge, N.J.

Srivastava, O.P. and B.C. Sethi. 1981. Contribution of farmyard manure on the buildup of available $\mathrm{Zn}$ in an aridisol. Commun. Soil Sci. Plant Anal. 12:355-361.

Swietlik, D. and J.V. LaDuke. 1991. Productivity, growth, and leaf mineral composition of orange and grapefruit trees foliar-sprayed with zinc and manganese. J. Plant Nutr. 14:129-142.

Wallihan, E.F., T.W. Embleton, and W. Printy. 1958. Zinc deficiency in the avocado. Calif. Agr. 12:4-5.

Whiley, A.W., K.G. Pegg, J.B. Saranah, and P.W. Langdon. 1987. Influence of phytophthora root rot on mineral nutrient concentrations in avocado leaves. Austral. J. Expt. Agr. 27:173-177.

Whiley, A.W., K.G. Pegg, J.B. Saranah, and P.W. Langdon. 1991. Correction of zinc and boron deficiencies and control of phytophora root rot of avocado by trunk injection. Austral. J. Expt. Agr. 31:575-578. 